\title{
ОСОБЛИВОСТІ ПСИХОНЕВРОЛОГІЧНИХ ЗМІН У ДІТЕЙ 3 ПОВТОРНИМИ ЕПІЗОДАМИ БРОНХООБСТРУКТИВНОГО СИНДРОМУ
}

\section{Дмитрихин Богдана Ярославівна \\ Кандидат медичних наук, доцент, кафедра педі- атрії №5 Національного медичного університету імені О. О. Богомольия, м. Київ (Украӥна)}

\section{Яскевич Ольга Ігорівна}

Кандидат психологічних наук, доиент, кафедра психології Украӥнського католицького університету, м. Львів (Україна)

\section{Бовкун Оксана Анатолї̈вна}

Кандидат медичних наук, асистент, кафедра педіатрї №5 Національного медичного університету імені О. О. Богомольия, м. Київ (Україна)

\section{Gсипова Світлана Іванівна}

Кандидат медичних наук, доиент, кафедра педіатрії №5 Начіонального медичного університету імені О.О.Богомольия, м. Київ (Україна)

\section{Дмитрииин Ольга Андрї̈вна}

\begin{abstract}
Магістр, асистент, кафедра педіатрії №5 Наџіонального медичного університету імені О. О. Богомольчя, м. Київ (Україна)
\end{abstract}

\begin{abstract}
Анотація. 3 р результатами аналізу педіатричних та психологічних наукових досліджень зроблено спробу простежити деякі взаємозв'язки розвитку повторних епізодів бронхообструкиії у дітей зі змінами їх психоневрологічного статусу. Представлено результати дослідження 45 дітей 7-14 років з повторними епізодами бронхообструктивного синдрому. Встановлено, щуо психовегетативний статус характеризується астенічними станами різного
\end{abstract}


ступеню вираженості, емоційними порушеннями, розладами сну; вегетативною дисфункиією у вигляді гіпергідрозу, артеріальної гіпертензї, стійкого червоного дермографізмом. Діти досліджуваної групи мають певні особистісні патерни реагування $i$ низьку фрустраційну толерантність у ситуаціях, які вимагають ствердження своєї автономії та сепарованого функиіонування. В основі цзього може лежати невирішений конфлікт близькості/дистанції в стосунках зі значимими фігурами розвитку, зокрема матір'ю. Визначене вище обтрунтовує доцільність проведення оцінки психологічного стану дітей з повторним обструктивним синдромом педіатром і психологом для попередження трансформаиії обструктивної респіраторної патологї в бронхіальну астму з вираженим соматопсихічним синдромом. Перспективами подальшого дослідження можуть стати питання доцільності психокорекцї чи психотерапї на фоні традиційного лікування в кожному конкретному випадку, вибір оптимальних методик психотерапевтичної взаємодіі.

Ключові слова: бронхообструктивний синдром, психоневрологічні зміни, діти.

Актуальність. В структурі захворюваності дітей віком від 0 до 17 років включно хвороби дихальної системи займають перше місце і складають біля 66\% [9, с. 13]. Особливості перебігу бронхолегеневих захворювань на сучасному етапі полягають у схильності до рецидивів і ускладнень, хронізації патологічних процесів. Відомо, що захворювання органів дихання 3 синдромом бронхіальної обструкції в практиці педіатра зустрічаються дуже часто, іноді мають тяжкий рецидивний перебіг. Згідно з даними досліджень, проведених за міжнародною стандартизованою програмою ISAAC, в Україні рецидивний синдром свистячого утрудненого дихання 3 подовженим видихом, так званий «wheezing», зустрічається майже у $30 \%$ дитячого населення [2, с.88; 3 , с.68; 9 , с.14]. У 30-50\% дітей у віці до 3-х років бронхообструктивний синдром (БОС) є частим ускладненням гострих респіраторних захворювань $[1$, с. $5 ; 7$, с. 40]. В свою чергу, у дітей $з$ інфекціями нижніх дихальних шляхів БОС зустрічається у $34 \%$ випадків, понад $50 \%$ із них мають повторні епізоди бронхіальної обструкції [1, с. 5], що майже у половині випадків з часом маніфестується у бронхіальну астму [1, с. $5 ; 12$, с. 46].

Термін «бронхообструктивний синдром» - це не самостійний діагноз. БОС - доволі гетерогенний стан, який може бути проявом багатьох нозологічних форм, це клінічний симптомокомплекс, пов'язаний 3 порушенням бронхіальної прохідності. Провідним патогенетичним механізмом БОС $є$ поширений запальний процес слизової бронхів. У разі розвитку повторних епізодів бронхіальної обструкції спостерігається тривале, затяжне запалення з розвитком гіперплазії слизової оболонки бронхіального дерева 
та зміни іiі структури. Все це зумовлює перебудову (ремоделінг) стінки бронха, тобто до основних компонентів БОС, а саме: бронхоспазму, набряку слизової оболонки бронхів та гіперсекреції слизу, приєднується ще один компонент, який сприяє хронізації процесу та значно погіршує прогноз захворювання. Клінічними проявами БОС є епізоди нав'язливого кашлю, утрудненого дихання з подовженим видихом, задишки, відчуття нестачі повітря, здуття грудної клітки, розсіяні, інколи дистанційні хрипи, неспокій, загальна слабкість [4, c.16].

Часто БОС може бути першим проявом різної патології, не лише органів дихання, визначати тяжкість перебігу основного захворювання та його прогноз. За даними літератури, у 50\% дітей з БОС, який виникає в перші три роки життя, спостерігається трансформація в органічний обструктивний синдром, а в інших $50 \%$ дітей БОС проходить без формування захворювання [1, с.5; 2, с. 88 ; 4, с.17]. Виявлення предикторів ризику рецидиву БОС при гострих респіраторних захворюваннях слід вважати актуальним і перспективним як з позиції практичної, так і наукової педіатрії. Це дозволить виділяти групу дітей високого ризику розвитку бронхіальної астми, які потребують активного тривалого профілактичного та протирецидивного лікування $[12$, с.48; 13 , с.67]. В цьому аспекті величезна роль відводиться вивченню зв'язків між різними тригерними факторами, в тому числі і психологічни- ми.

Встановлено значний вплив психоемоційних процесів у виникненні, перебігу та лікуванні бронхіальної обструкції. Гіпоксія, яка супроводжує рецидивні та хронічні захворювання легень, викликає нейропсихологічні порушення; останні в свою чергу, поглиблюють соціальну дезадаптацію, що знижує якість життя дітей. Відомо, що психологічні фактори можуть впливати на перебіг захворювання, його важкість та результат, тому соматичну патологію доцільно розглядати у взаємозв'язку з психологічними факторами, які можуть виступати у ролі тригерів, що запускають загострення, або модуляторів, які впливають на перебіг захворювання [8, с.2].

Врахування психологічних чинників поряд 3 вивченням особливостей клінічного перебігу, імунного та вегетативного статусу дасть можливість більш диференційованого підходу до терапії дітей з рецидивним БОС.

\section{Аналіз останніх досліджень і публі-} кацій.

Проблемам психосоматичних співвідношень присвячені дослідження вченихмедиків, таких як Б. В. Михайлов, Є. М. Харченко, О. С. Чабан, А. І. Сердюк, Д. М. Ісаєв та інші; психологічні дослідження, пов'язані з психосоматичними захворюваннями у дітей проводяться рідко (Г. О. Аріна, Н. О. Коваленко, Ж. Кламмер).

Особливості психоневрологічного статусу дітей $з$ хронічними бронхолегеневими 
захворюваннями особливо привертають увагу педіатрів, зважаючи на те, що патологія органів дихання займає перше місце серед всієї дитячої захворюваності. Тяжкий перебіг, тривалі обмеження в соціальній, сімейній та інших сферах життя накладають відбиток на особистість хворого, формують певні, раніше не властиві йому риси характеру, диктують правила у стосунках з зовнішнім світом.

Доведено, що у хронічно хворої дитини формується особливий внутрішній світ, побудований зі складних поєднань сприймань та відчуттів, емоцій та конфліктів, психічних травм, переживань та спогадів (B. В. Ніколаєва, О. Т. Соколова, О. В. Іванова, І. Г. Кіян, І. С. Равич-Щербо, А. Г. Рум'янцев, I. М. Нікольська, Р. М. Грановська). Поняття «внутрішньої картини хвороби» розкривають дослідження Р. А. Лурія, вказуючи на те, що у випадку тяжкої хронічної хвороби внутрішній світ дитини починає заломлюватися крізь призму внутрішньої картини хвороби.

Серед хронічних серйозних захворювань органів дихання у дітей першість належить бронхіальній астмі, тому власне це захворювання як класичне психосоматичне найчастіше привертало увагу педіатрів, невропатологів, психологів. Сутність, структуру й особливості формування внутрішнього світу дитини, хворої на бронхіальну астму, а також фактори, що впливають на процеси становлення та наповнення іï внутрішнього світу розк- риває у своїх дослідженнях Шмігель Н. С. Автором проаналізовано соціально-психологічні передумови створення неадекватної внутрішньої картини хвороби у дітей з бронхіальною астмою, формування особистісних рис дитини за умов тяжкого перебігу патологічного процесу $[17$, c.20].

Беш Л. В., Крючко О. М., Хайтович М. В., Лапшин В. Ф., Недельська С. М. вважають бронхіальну астму класичним психосоматичним захворюванням, у перебігу якого беруть участь психосоціальні фактори [4, с.17; 10,с.36; 15, с.28], що впливають на навчання, фізичну активність, спілкування, емоційне самопочуття [13, с.67]. Бурбела Є. I., Константинович Т. В. визначають психопатологічні складові бронхіальної обструкції [5, c.34; 8, с.5], Лапшин В. Ф., Крючко О. М. обгрунтовують доцільність включення до реабілітаційних комплексів у дітей з бронхіальною астмою заходів психокорекції та психотерапії $[6$, c.24; 7, с.41]. Питанням підвищення якості життя, налагодження освітніх програм для хворих дітей та їх батьків з обов'язковим залучення психолога присвячені роботи Беш Л. В., Процюк Т. Л., Уської В. Р. [4, с.17; 13, с.68; 14, с.20], необхідність знань медичної психології лікарям, які працюють з дітьми, хворими на бронхіальну астму, рекомендує законодавчо затвердити в «Протоколах діагностики та лікування бронхіальної астми у дітей» С. М. Недельська [11, с.59].

Діти зі встановленим і підтвердженим 
діагнозом бронхіальної астми найчастіше лікуються у профільних відділеннях пульмонології, алергології, де їм проводиться комплексна терапія, включаючи психотерапію. Проте повторні епізоди бронхіальної обструкції, інколи неадекватно та несвоєчасно ліковані, наслідком яких може стати бронхіальна астма, підлягають госпіталізації і лікуванню в соматичних відділеннях дитячих стаціонарів як гострої патології. Часті та тривалі госпіталізації дітей з БОС потребують комплексного, в тому числі психоневрологічного обстеження пацієнтів та надання їм психологічної допомоги.

Актуальним залишається питання щодо первинності чи вторинності неврологічних змін стосовно до основної патології, зокрема на тлі доведення факту тісного зв'язку нервової та імунної систем; діагностики та корекції вторинних психоневрологічних змін на тлі повторних епізодів бронхообструкції у дітей. Все це визначило актуальність і мету нашого дослідження.

Постановка завдання. Мета дослідження - вивчення психоневрологічних змін у дітей з частими епізодами обструктивного синдрому для своєчасної комплексної превентивної терапії щодо розвитку бронхіальної астми.

Матеріали та методи. За результатами ретроспективного спостереження за 56 дітьми молодшого та середнього шкільного віку 3 частими респіраторними захворюваннями 3
БОС в дитячій клінічній лікарні №3 Солом’янського району міста Києва виявлено, що нервово-психічні розлади в тій чи іншій формі спостерігаються у 89,3\% дітей. Вони з'являлися після декількох епізодів перенесеного захворювання і утримувались у середньому впродовж півроку у разі відсутності повторних епізодів.

У дослідженні брали участь 45 дітей 7 14 років з повторними епізодами БОС, які перебували на стаціонарному лікуванні в соматичному відділенні дитячої клінічної лікарні. Психологічні обстеження проводилися в рамках щоденних занять 3 психологом, які були включені в діючий тижневий навчальний проект для дітей і мали за мету насамперед налаштувати дітей на конструктивну співпрацю 3 лікарями, батьками та однолітками.

Групу порівняння склало 25 дітей такого ж віку зі спорадичними випадками ГРВI без синдрому обструкції. Всі діти обстежені згідно 3 протоколами діагностики та лікування пацієнтів за спеціальністю «Дитяча пульмонологія»: всім дітям проводили загальноклінічне обстеження, консультацію невропатолога, ехо-, електроенцефалографію з метою виключення органічної патології. Психологічне обстеження здійснювалось в два етапи. Перший етап включав скринінгове тестування за такими методиками: тест для визначення рівня невротизації Айзенка, тест фрустраційної толерантності Розенцвейга, тест колірних виборів Люшера (в розробленій Стані- 
славським модифікованій версії для виявлення домінуючих захисних механізмів у стосунку з об'єктом). Перший етап проводився в рамках літньої виробничої практики студентами 4-5 курсу медико-психологічного факультету Національного медичного університету імені О. О. Богомольця. На другому етапі лікаремпсихологом проводилось діагностичне психодинамічно-орієнтоване інтерв'ю (клінічна бесіда).

Результати досліджень та їх обговорення. Серед виявлених порушень у дітей 3 рецидивним обструктивним синдромом найчастіше мали місце астенічні зміни різного ступеню $(68,9 \%)$, які характеризувалися в основному емоційними, в меншій мірі сенсорними та руховими розладами. Емоційні порушення домінували у вигляді невмотивованого коливання настрою - пригнічення або емоційне збудження (вимушений сміх, надмірна радість, безпричинні сльози, екзистенціальні страхи). Крім того, серед проявів астенії часто спостерігали знижену фізичну активність (55,6\%), втрату працездатності $(37,8 \%)$. У половини дітей основної групи визначалися зниження інтелектуальної працездатності, погіршення пам'яті.

Характерними для дітей з частими обструкціями дихальних шляхів були розлади сну ( $80 \%$ випадків): сповільнене засинання, безсоння, поверхневий нічний сон, часті тяжкі сновидіння, сонливість вдень. Крім того, у майже половини дітей виявили істероїдні риси характеру, зокрема егоцентризм, демонстратизм у мові та поведінці. Вегетативна дисфункція (55,6\% дітей основної групи) проявлялася гіпергідрозом, тенденцією до артеріальної гіпертензії, стійким червоним дермографізмом, частими головними болями, головокружінням.

3'ясовано, що рівень нейротизму у дітей, які часто хворіють на респіраторну патологію з синдромом обструкції, дещо вищий у порівнянні 3 іншою групою (у 44,4\% проти 12\%). Цим дітям властива емоційна лабільність, поєднана зі зниженням екстравертованості, що проявляється деякою загальмованістю та інертністю.

У обстежених дітей основної групи визначаються наступні риси особистості: - підвищена сенситивність (схильність до сильних емоційних реакцій, чутливість до стосунків 3 людьми, потреба співчуття, співпереживання); - знижена гіпертимність (вітальна сила), що пояснює зниження ініціативності, активності, песимізм; - інертність афекту, «застопорення» на якійсь емоції; - дистимність (зниження настрою), що формує поведінкові реакції.

За результатами тесту Люшера зелений колір (основний, що разом з червоним відповідає за самозбереження) у половини обстежених основної групи витіснений у блок групи байдужих чи відторгнених кольорів, тоді як коричневий (пасивний) перемістився до зони основних. Це свідчить про зниження активного зацікавлення життям, потребу спокою, відмову від боротьби за автономію та самоствер- 
дження. У дітей групи порівняння результати тестування відповідали віковим нормам.

Таким чином, проведене нами на першому етапі психологічне дослідження свідчить, що часті епізоди респіраторних захворювань у поєднанні з БОС мають значний несприятливий вплив на психологічний статус дітей і сприяють значній психічній травматизації хворих.

На другому етапі обстеження проведено діагностичне психодинамічно-орієнтоване інтерв'ю. Узагальнено, його результати свідчать про те, що діти 3 досліджуваної групи мають певні особистісні патерни реагування i низьку фрустраційну толерантність у ситуаціях, які вимагають ствердження своєї автономії та сепарованого функціонування, в основі чого може лежати невирішений конфлікт близькості/дистанції в стосунках зі значимими фігурами розвитку (матір чи інші особи, які виконують материнську функцію, зокрема щоденний догляд). Ймовірно, особистісна констеляція має не тільки супутню, але й етіологічну вагу, що підтверджує психотерапевтична практика.

Відомо, що на тлі хронічного соматичного захворювання часто формується соматопсихічний синдром, який протікає як соматоформна вегетативна дисфункція, астеноневротичний розлад, тривожний та депресивний розлади, що відрізняються широким поліморфізмом $[15$, с.28; 16, с.96]. Узагальнено взаємодію психічного синдрому з основним сомати- чним захворюванням можна подати у вигляді наведених нижче співвідношень:

1. Соматичне захворювання стало безпосередньою причиною розвитку психічного синдрому (наприклад, прогресуюча задишка у хворих на астму часто викликає депресивну симптоматику).

2. Соматичне захворювання прискорює виникнення психічних синдромів у осіб, які схильні до цього.

3. Психічний розлад розвивається як реактивний стан на тяжке хронічне соматичне захворювання.

4. Соматичне захворювання i психічний розлад не пов'язані між собою.

У перших двох випадках терапевтична тактика спрямована на лікування соматичного захворювання. У третьому - поряд із лікуванням основного соматичного захворювання проводять навчальну та психотерапевтичну роботу. У четвертому випадку відразу потрібно проводити специфічну терапію за обома напрямками [8, с. 4].

Встановлено, що психоневрологічні розлади, які формуються на фоні частих епізодів респіраторної патології з синдромом бронхіальної обструкції, негативно впливають на перебіг захворювання, збільшуючи їх тяжкість, частоту та тривалість госпіталізацій, а також частоту викликів швидкої допомоги для надання невідкладної допомоги.

Зважаючи на те, що повторні рецидивні обструкції дихальних шляхів у дітей розгляда- 
ються педіатрами як передастма, доцільно здійснювати превентивну терапію в кількох напрямках, таких як рання діагностика чинників ризику трансформації рецидивного обструктивного синдрому в бронхіальну астму; своєчасне виявлення та корекція психоневрологічних змін; освітні програми для дітей та батьків з метою покращення якості життя.

Так, Охотнікова О. М. пропонує для своєчасного виявлення бронхіальної астми у дітей наступні діагностичні критерії: три і більше епізодів бронхообструкції або wheezing, чи синдром крупу, або сухого нападоподібного кашлю впродовж одного року за наявності у дитини поліорганних проявів атопії, насамперед, алергічного риніту i/або атопічного дерматиту, та обтяженої з атопії спадковості, перш за все, по лінії матері. Підвищує ймовірність діагнозу бронхіальної астми наявність алергічної сенсибілізації за даними алергологічного дослідження: збільшення рівня загального IgE та специфічних IgE-антитіл до різних екзоалергенів. Підтвердженням діагнозу бронхіальної астми є позитивна відповідь на пробну бронхолітичну та превентивну базисну терапію [12, с. 50].

Своєчасне виявлення та корекція психоневрологічних змін у дітей може проводитися спільно педіатром і психологом в умовах амбулаторної та стаціонарної ланки. Існують скринінгові тести для верифікації попереднього діагнозу межових зсувів у рамках астеноневротичного синдрому (методика дослідження рівня невротизації за Л. І. Вассерманом); тривожних станів (методику діагностики самооцінки тривоги за Ч. Д. Спілбергером, Ю. Л. Ханіним та експрес-метод визначення рівня тривоги за I. В. Молдовану Н. Г. Шпитальниковою ); критерії депресивного синдрому [8, с.3]. Доцільність, тактика, тривалість фармакотерапії психовегетативних розладів у дітей з рецидивним обструктивним синдромом вирішують спільно педіатр, алерголог/пульмонолог, психолог/психотерапевт, психіатр.

3 метою підвищення ефективності лікування та попередження повторних епізодів бронхіальної обструкції ми започаткували освітню програму для батьків дітей з захворюваннями органів дихання з обтяженим алергологічним анамнезом. Ця програма реалізувалася в наступних напрямках: індивідуальні бесіди-заняття з батьками в стаціонарі; конференції для батьків; випуск спеціальних допоміжних матеріалів (проспекти, брошурки тощо). Перша бесіда включала коротке анкетне опитування, яке дозволяло нам оцінити рівень знань батьків про патологію у дітей. Встановлено, що переважна більшість батьків раніше не отримувала належної інформації, не вбачала потреби своєчасного комплексного лікування дитини. В результаті багаторазових бесід 3 педіатром 75,6\% батьків поглибили свої знання про суть патології, усвідомили необхідність тривалого лікування та корекції не тільки респіраторної симптоматики, але й ін- 
ших, зокрема, психоневрологічних порушень.

\section{Висновки і перспективи подальшого} дослідження. Психовегетативний статус дітей 3 частими епізодами респіраторної патології 3 БОС характеризується астенічними станами різного ступеню вираженості, емоційними порушеннями, які відзначалися пригніченістю та невмотивованістю коливань настрою, розладами сну; вегетативною дисфункцією, що проявлялася гіпергідрозом, тенденцією до артеріальної гіпертензії, стійким червоним дермографізмом у більшості пацієнтів, порівняно з групою дітей зі спорадичними випадками ГРВI без синдрому обструкції. Визначене вище обгрунтовує доцільність проведення оцінки психологічного стану дітей 3 повторним обструктивним синдромом педіатром і психологом для своєчасної комплексної терапії та попередження трансформації обструктивної респіраторної патології в бронхіальну астму з вираженим соматопсихічним синдромом. А доцільність психотерапії на фоні традиційного лікування на даному етапі розвитку хвороби, вибір оптимальних методик, рівнів психотерапевтичної взаємодії може становити перспективи подальшого дослідження.

\section{Перелік використаних джерел:}

1. Абатуров $O . \in$. Фактори ризику розвитку бронхіальної обструкції при гострих бронхітах у дітей раннього віку / О. С. Абатуров, О. О. Русакова // Международный журнал педиатрии, акушерства и гинекологии, 2014. Т.6, № 1.-С.5.
2. Аряев Н. Л. Атопический дерматит в практике педиатра/ Н. Л. Аряев, В. А. Клименко,А.И. Кожемяка, В.А. Феклин - К., - 2007.-88 с.

3. Беш Л. В. Алергічний марш: перспективи профілактики і прогнозу / Л. В. Беш - Львів: Каменяр. - 2010. $68 \mathrm{c}$.

4. Беш Л. В. Нове в діагностиці і терапії бронхіальної астми у дітей: практичний підхід до трактування найсучасніших вітчизняних та міжнародних узгоджувальних документів / Л. В. Беш // Здоров'я України. - 2014. -№ 1 (25) - C.16-17.

5. Бурбела Е. I. Психопатологічна компонента бронхообструктивного синдрому (огляд літератури) / Е. І. Бурбела // Перинатология и педиатрия. - 2013. - № 3. - С. 33 - 35. - Режим доступу: http://nbuv.gov.ua/j-pdf/ perynatology_2013_3_10.pdf

6. Крючко О. Психосоматичні концепції в сучасній педіатрії / О. Крючко // Мистецтво лікування. - 2006. №6. С. 23-25. - Режим доступу: http://m-l.com.ua/? aid $=802$.

7. Лапшин В. Ф. Обгрунтування диференційованих реабілітаційних комплексів у дітей з бронхіальною астмою /В.Ф. Лапшин, Ю.Г. Антипкін, Т.Р. Уманець // Астма та алергія. - 2002. - №2. - С. 39-42.

8. Константинович Т. В. Психологічний статус хворих на бронхіальну астму та методи його корекції //Газета «Новости медицины и фармации» Аллергология и пульмонология 2008 (тематический номер). [Электронный ресурс].- Режим доступа: http:// www.mif-ua. com/archive/issue-5161/

9. Моісеєнко Р. О. Аналіз та тенденції захворюваності дитячого населення України / Моісеєнко Р. О., Соколовська Я. І., Кульчицька Т. К., Бухановська Т. М. // Современная педиатрия. - 2010. - № 3(31). - С. 13-18.

10. Недельська С. М. Медико-психологічна характеристика особистості хворої на бронхіальну астму дитини середнього та старшого шкільного віку/ С. М. Недельська, О. Ю. Акулова // Педіатрія, акушерство та гінекологія - 2012. т. 75, № 2. - С. 35 - 38.

11. Недельська C. М. Методичні питання оптимізації 
санітарно-просвітницької допомоги дітям, які хворі на бронхіальну астму, в умовах реформування галузі охорони здоров'я України / С. М. Недельська, О. Ю. Акулова // Запорожский медицинский журнал2013. - № 4 (79). - C.58-60.

12. Охотнікова О. М. Синдром бронхіальної обструкції у дітей: диференційна діагностика та лікування. Мистецтво лікування. 2010; 1(67):46-52.

13. Процюк Т. Л. Якість життя хворих на бронхіальну астму дітей та чинники, що впливають на неї/ Т. Л. Процюк // Актуальні питання фармацевтичної і медичної науки та практики. - 2013. - № 3. - С. 66-68. - Режим доступу: http://nbuv.gov.ua/j-pdf/apfimntp_2013_3_21.pdf 14. Уська В. Р. Вплив освітньої програми на ефективність лікування бронхіальної астми в дітей: автореф. дис. канд. мед. наук: 14.03.10 / Державний вищий навчальний заклад «Тернопільський держ. медичний ун-т ім. І.Я. Горбачевського». - Т., - 2008. - 20 с.

15. Хайтович $M$. В. Психосоматичний підхід у педіатрії: історія і сучасність/М. В. Хайтович // Здоров'я України. - 2013, - №2.- С.28-29.

16. Чабан О. С. Психосоматична медицина (аспекти діагностики та лікування): Посібник / О.С. Чабан, О.О. Хаустова. - К.: ТОВ «ДСГ Лтд», 2004. - 96 с.

17. Шмігель Н. С. Психологічні особливості внутрішнього світу дітей, хворих на бронхіальну астму: автореф. дис. канд. психол. наук: 19.00.04 / АПН України. Ін-т психології ім. Г. С. Костюка. К., - 2008. - 20 с.

\section{References (Transliteration):}

1. Abaturov O. Je. Faktory ryzyku rozvytku bronhialnoi obstrukcii pry gostryh bronhitah u ditej rannogo viku / O. Je. Abaturov, O. O. Rusakova // Mezhdunarodnyjzhurnalpediatrii, akusherstva i ginekologii, -2014. T.6, № 1. p.5.

2. Aryaev N. L. Atopycheskyj dermatyt v praktyke pedyatra/ N. L. Aryaev, V. A. Klymenko,A.Y. Kozhemyaka, V.A.Fekly`n - K., 2007. 88 s.
3. Besh L. V. Alergichnyj marsh: perspektyvy profilaktyky i prognozu / L. V. Besh - Lviv: Kamenyar. 2010. 68 s.

4. Besh L. V. Nove $\mathrm{v}$ diagnostyci i terapii' bronhial'noi' astmy $\mathrm{u}$ ditej: praktychnyj pidhid do traktuvannjanaj suchasnishyh vitchyznjanyh ta mizhnarodnyh uzgodzhuval'nyh dokumentiv. / L. V. Besh // Zdorov'ja Ukrai'ny. - 2014. - № 1(25) - pp.16-17.

5. Burbela E. I. Psyhopatologichna komponenta bronhoobstruktyvnogo syndromu (ogljad literatury) / E. I. Burbela // Perynatologyja y pedyatryja. - 2013. -№ 3. -pp. 33-35. - http://nbuv.gov.ua/j-pdf / perynatology _2013_ 3_10.pdf.

6. Krjuchko O. Psyhosomatychni koncepcii v suchasnij pediatrii / O. Krjuchko // Mystectvo likuvannja. - 2006. -№ 6. -pp. 23-25. - http://m-1.com.ua/?aid=802.

7. Lapshyn $\quad V . \quad F$. Obgruntuvannja dyferencijovanyh reabilitacijnyh kompleksiv u ditej z bronhialnoju astmoju / V.F. Lapshyn, Ju.G. Antypkin, T.R. Umanec // Astma ta alergija. - 2002. - № 2. -pp. 39-42.

8. Konstantynovych T. V. Psyxologichnyj status xvoryx na bronxialnu astmu ta metody jogo korekciyi //Gazeta «Novosty medycyny y farmacyy» Allergologyya y pulmonologyya 2008 (tematycheskyj nomer). [Elektronnyj resurs].- Rezhym dostupa: http://www.mif-ua. com/ archive/issue-5161/

9. Moyseyenko R. O. Analiz ta tendenciyi zaxvoryuvanosti dytyachogo naselennya Ukrayiny / Moiseyenko R. O., Sokolovska Ya. I., Kulchyczka T. K., Buxanovska T. M. // Sovremennaya pedyatryya. - 2010. - № 3 (31). - S. 13-18. 10. Nedelska S. M. Medyko-psyhologichna harakterystyka osobystosti hvoroi na bronhialnu astmu dytyny serednogo ta starshogo shkilnogo viku/ S. M. Nedelska, O. Ju. Akulova // Pediatrija, akusherstvo ta ginekologija-2012. Vol.75, №2. - pp.35-38.

11. Nedelska S. M. Metodychni pytannja optymizacii sanitarno-prosvitnycnoi dopomogy ditjam, jaki hvori na bronhialnu astmu, v umovah reformuvannja galuzi ohorony zdorovja Ukrainy / S. M. Nedelska, O. Ju. Akulova // Zaporozhskij medycynskij zhurnal-2013. - № 4 (79). pp.58-60. 
12. Oxotnikova O. M. Syndrom bronxialnoyi obstrukciyi u ditej: dyferencijna diagnostyka ta likuvannya. Mystecztvo likuvannya. 2010; 1(67):46-52.

13. Procjuk T. L. Jakist zhyttja hvoryh na bronhialnu astmu ditej ta chynnyky, shho vplyvajut na nei / T. L. Procjuk // Aktualni pytannja farmacevtychnoi i medychnoi nauky ta praktyky. - 2013. - № 3. - pp. 66-68. - http://nbuv.gov.ua/jpdf/apfimntp_2013_3_21.pdf

14. Uska $V$. R. Vplyv osvitnoi programy na efektyvnist likuvannja bronhialnoi astmy $\mathrm{v}$ ditej: avtoref. dys. kand. med. nauk: 14.03.10 / Derzhavnyj vyshhyj navchalnyj zaklad «Ternopilskyjderzh. Medychnyj un-t im. I.Ja.Gorbachevskogo».- T., - 2008. -20 p.

15. Hajtovych M. V. Psyhosomatychnyj pidhid u pediatrii: istorija i suchasnist / M. V. Hajtovych // Zdorov'ja Ukrainy. - 2013, - № 2. - pp.28-29.

16. Chaban O. S. Psyhosomatychna medycyna (aspekty diagnostyky ta likuvannja): Posibnyk / O.S. Chaban, O.O. Haustova. - K.: TOV «DSG Ltd», -2004. - 96 p.

17. Shmigel N. Je. Psyhologichni osoblyvosti vnutrishnogo svitu ditej, hvoryh na bronhial'nu astmu: avtoref. dys. kand. psyhol. nauk: 19.00.04 / APN Ukrainy. In-t psyhologii' im. G. S. Kostjuka. -K., - 2008. - 20 p.

\section{Dmytryshyn Bohdana}

Candidate of Medical Science, Assistant Professor of pediatrics department № 5, Bogomolets National Medical University, Kyiv (Ukraine)

\section{Yaskevych Olha}

PhD, Psychology department, Ukrainian Catholic University, Lviv (Ukraine)

\section{Bovkun Oxana}

Candidate of Medical Science, Assistant Professor of pediatrics department № 5, Bogomolets National Medical University, Kyiv (Ukraine)

\section{Yesypova Svitlana}

Candidate of Medical Science, Assistant Professor of pediatrics department № 5, Bogomolets National Medical Uni- versity, Kyiv (Ukraine)

\section{Dmytryshyn Olha}

Master of Medical Science, Assistant Professor of pediatrics department № 5, Bogomolets National Medical University, Kyiv (Ukraine)

\section{PECULARITIES OF CHILDREN'S PSY- CHONEUROLOGICAL CHANGES WITH REPEATED EPISODES OF BRONCHOOB- STRUCTIVE SYNDROME}

\section{ABSTRACT}

Purpose of the article - to study children's psychoneurological changes with frequent episodes of bronchoobstructive syndrome for urgent complex preventive therapy of bronchial asthma development.

Results of research within children aged $7-14$ with repeated episodes of bronchoobstructive syndrome are showed as well as 25 children of the same age with sporadic cases of A.R.V.I. without obstructive syndrome. Psychological examination was done in two steps: selective testing (Eysenck test, Rosenzveig test of frustration tolerance, Lusher test of colour choices) and diagnostic psychodynamic interview made by psychologist.

It was stated that within $89,3 \%$ of children were found asthentic changes, emotional disorder, decrement of physical activity and working efficiency. Decrement of intellect and memory deterioration were found within half of the children. Sleep disorders were characteristic $(80 \%$ of cases); half of the children formed hysteroid features of the character, in particular egocentrism 
and demonsratism in speech and behavior. Vegetative dysfunction was evident by hyperhidrosis, tendency to arterial hypertension, firm red dermographism, frequent headaches and dizziness $(55,6 \%$ of children). The level of neuroticism with these children was quite higher: emotional lability connected with decrease of extroversion was determined with lethargy and inertness. Advanced sensitivity, decreased hyperthymism that explains the decrease of initiativity, activity and pessimism; inertness of affect, fixation on any emotions; dysthymia took place.

According to the Lusher test green colour within half of the tested of the main group was pushed into indifferent block or sawn-off colours block, at the same time brown colour moved to the zone of main ones. It states about lowering of concernment in life, abruption of need in autonomy and self-affirmation and willingness of calm.

The results of the second stage show that children of the examinational group have some individual patterns (types) of reaction and low frustration tolerance in situations that require estimation of their autonomy and abstract (separated) functioning. Unsolved conflict closeness/distance in relationship with signify figures of development, mother in particular, may lie in the basics of it.

Therefore, conducted research shows that frequent episodes of bronchoobstructive syndrome have significant negative effect on psychoneurological state of children and require further study and correction. Perspectives of the further research might be issues of practicability of psych correction or psychotherapy in the face of traditional treatment in every particular case, choice of optimal methods and levels of psychotherapy interaction.

Key words: bronchoobstructive syndrome, psychoneurological changes, children.

\section{Дмитришин Богдана Ярославовна}

Кандидат медицинских наук, доцент кафедры педиатрии №5 Национального медицинского университета имени Богомольияа, г. Киев (Украина)

\section{Яскевич Ольга Игоревна}

Кандидат психологических наук, дочент кафедры психологии Украинского католического университета, $а$. Львов (Украина)

\section{Бовкун Оксана Анатольевна}

Кандидат медицинских наук, ассистент кафедры педиатрии №5 Наџионального медицинского университета имени Богомольияа, г. Киев (Украина)

\section{Ссипова Светлана Ивановна}

Кандидат медицинских наук, доиент кафедры педиатрии №5 Национального медицинского университета имени Богомольца, г. Киев (Украина)

\section{Дмитришин Ольга Андреевна}

Магистр, ассистент кафедры педиатрии №5 Наџионального медицинского университета имени Богомольй, г. Киев (Украина)

\section{ОСОБЕННОСТИ ПСИХОНЕВРОЛОГИЧЕ- СКИХ ИЗМЕНЕНИЙ У ДЕТЕЙ С ПО- ВТОРНЫМИ ЭПИЗОДАМИ БРОНХООБ- СТРУКТИВНОГО СИНДРОМА}

Аннотация. Цель статьи - изучение психоневрологических изменений у детей с 
частыми эпизодами обструктивного синдрома для своевременной комплексной превентивной терапии развития бронхиальной астмы.

Представлены результаты исследования 45 детей 7 - 14 лет с повторными эпизодами бронхообструктивного синдрома и 25 детей такого же возраста со спорадическими случаями ОРВИ без синдрома обструкции. Психологическое обследование осуществлялось в два этапа: выборочное тестирование (тест Айзенка, тест фрустрационной толерантности Розенцвейга, тест цветовых выборов Люшера) и диагностическое психодинамическоеориентированное интервью, которое проводил врач-психолог.

Установлено, что у 89,3\% детей проявлялись астенические изменения, эмоциональные расстройства, снижение физической активности и работоспособности. У половины детей определялись снижение интеллекта, ухудшение памяти. Характерными были расстройства сна (в 80\% случаев); у половины детей формировались истероидные черты характера, в частности эгоцентризм, демонстратизм в языке и поведении. Вегетативная дисфункция проявлялась гипергидрозом, тенденцией к артериальной гипертензии, стойким красным дермографизмом, частыми головными болями, головокружением (55,6\% детей). Уровень нейротизма у таких детей был несколько выше; эмоциональная лабильность, сочетанная со сниженной экстравертностью, определялась некоторой заторможенностью и инертностью. Имели место повышенная сенситивность, сниженная гипертимность, что объясняет снижение инициативности, активности, пессимизм; инертность аффекта, фиксацию на любой эмоции; дистимность. По результатам теста Люшера зеленый цвет у половины обследованных основной группы был вытеснен в блок группы равнодушных или отверженных цветов, тогда как коричневый переместился в зону основных, свидетельствует о снижении активного интереса к жизни, отторжение потребности в автономии и самоутверждении, желание покоя.

Результаты второго этапа свидетельствуют о том, что дети исследуемой группы имеют определенные личностные паттерны реагирования и низкую фрустрационную толерантность в ситуациях, которые требуют утверждения своей автономии и сепарированного функционирования. В основе этого может лежать нерешенный конфликт близости / дистанции в отношениях со значимыми фигурами развития, в частности матерью.

Таким образом, проведенное нами исследование показывает, что частые эпизоды бронхообструктивного синдрома имеют существенное неблагоприятное воздействие на психоневрологический статус детей, требуют дальнейшего изучения и коррекции. Перспективами дальнейшего исследования могут стать вопросы целесообразности психокоррекции или психотерапии на фоне традиционного лечения в каждом конкретном случае, выбор 
оптимальных методик, уровней психотерапевтического взаимодействия.

Ключевые слова: бронхообструктивный синдром, психоневрологические измене-

ния, дети. 